\title{
FACTORS AFFECTING THE THICKNESS OF REPLACEMENT LAYER ON MEDIUM CLAY
}

\author{
Manar Abd Elhamid ${ }^{1,2}$, Tarek Abdelaziz ${ }^{3}$, and Hesham Bassioni ${ }^{4}$ \\ ${ }^{1}$ School of Civil Engineering, College of Engineering, Univirsiti Teknologi Malaysia, Johor Bahru, \\ Malaysia, Tel: +601136363959, e-mail: gaafar.m@graduate.utm.my
}

${ }^{2}$ Department of Construction and Building Engineering, College of Engineering and Technology, Arab
Academy for Science, Technology and Maritime Transport, Alexandria, Egypt, Tel: +201286372695, e-mail:
manar.abdelhamid@ aast.edu

${ }^{3}$ Department of Construction and Building Engineering, College of Engineering and Technology, Arab Academy for Science, Technology and Maritime Transport, Alexandria, Egypt, Tel: +201006632307, e-mail: Tareqmaziz@yahoo.com.

${ }^{4}$ Department of Construction and Building Engineering, College of Engineering and Technology, Arab
Academy for Science, Technology and Maritime Transport, Alexandria, Egypt, Tel: +201001240110, e-mail:
hbassioni@ @aast.edu.

Received Date: September 17, 2020; Revised Date: June 6, 2021; Acceptance Date: November 12, 2021

\begin{abstract}
Soil replacement is a common technique that can be used to increase the soil bearing capacity and reduce the expected settlement. The thickness of replacement layer depends on many factors such as: the applied stress, original soil properties, material of replacement layer and the cost of foundation works. However, until now the practical thickness of replacement is usually selected based on soil experts' experience. This study proposed an optimization model to assist geotechnical engineers in predicting the optimum thickness and material type of replacement layer that satisfy the main design requirements, i.e. bearing capacity, consolidation settlement and cost considerations at the same time. The Evolutionary solving method that uses a variety of genetic algorithm and local search methods was used to solve the research problem. Furthermore, the effect of the thickness and properties of clay layer and the depth of ground water table on determining optimum type and thickness of replacement soil were investigated. The study evaluated the relationship between the replacement layer thickness and the total direct cost of foundation works and found that, the notion of increasing replacement thickness to decrease cost limitlessly was not viable and an optimal thickness was usually achieved.
\end{abstract}

Keywords: Clay, Cost, Foundation, Optimization model, Replacement thickness, Settlement, Soil replacement

\section{Introduction}

Soil replacement is one of the most familiar techniques that can be used to improve the shear strength, increase the bearing capacity and reduce consolidation settlement beneath shallow foundations [1]. Replacing the entire weak soil is not practical because of the high costs involved, so that partial replacement is a feasible solution considering the cost factor [2]. However, till this moment, there is a shortage of studying the different factors which strongly affect the determination of replacement layer thickness. In most of cases, the optimum replacement layer thickness is determined based on experience and may cause unnecessary cost [3]. Many studies have investigated soil replacement technique. Most of these studies focused on increasing soil bearing capacity and / or decreasing the expected soil settlement [4], [5], [6], [7], [8]. On the other hand, there is a lack of studies that consider the cost of foundation works as one of the governing factors when selecting the replacement layer 
thickness. This cost of foundation works is very important factor as well as increasing the soil bearing capacity and decreasing settlement. For example, a major cost burden was reported in the La Rosita power plant in Mexico due to the unnecessary increase in soil replacement thickness by $1 \mathrm{~m}$ [8]. Therefore, the objective of this paper is to investigate the main factors affecting the required thickness of replacement layer through developing a computer model that determine the optimal replacement layer thickness and the most suitable type of replacement layer's material. The results could be used to achieve minimum total foundation construction cost and reduce consolidation settlement beneath the foundation at the same time. This paper is further comprised of the following sections: Soil Replacement as a Soil Improvement Technique, Optimization Model, Computer Model, Parametric Study, and Conclusions. Figure (1) shows the soil profile used during this study.

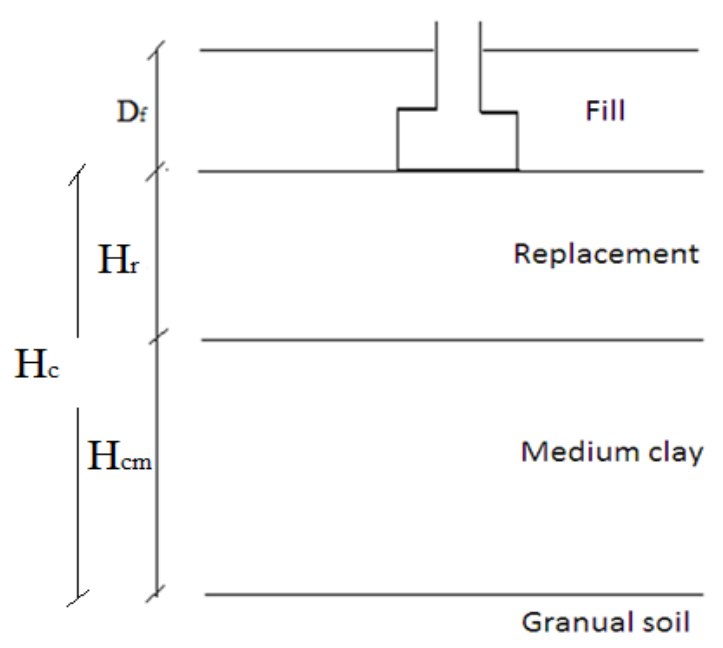

Figure 1: The soil profile used in the study

\section{Soil Replacement as a Soil Improvement Technique}

The soil formation in many regions worldwide is composed of a deep layer of soft to medium clay followed by harder layers of granular soils or rocks. If the soil is weak and cannot sustain the high superstructure stresses, one of the best alternatives is replacement of the weak soil layer, totally or partially, by a layer of stronger soil. The use of replacement soil under shallow foundation can reduce consolidation settlement and improve bearing capacity. It has some advantages over the other improvement techniques and deep foundation. It can be more economical and requires less delay to construction time in comparison with other techniques [3]. Varghese [9] stated that the foundation condition can be improved by replacing the part of medium clay with more competent materials such as sand; gravel or crushed stone. He also defined the region of high stress in a shallow foundation is only 1 to 1.5 its breadth and this part can be replaced by selected good soil. Abdel Salam [5] investigated the most practical thickness of replacement soil which could be used to reduce vertical settlement under foundation for a wide range of deep soft clay layer by using finite element technique. He found that the optimal replacement layer thickness is ranging from $(0.5: 1.25)$ times the width of footing (B). Abdel Fatah [4] also studied the improvement of soft clay behaviour by using different thicknesses of replacement soil beneath shallow foundation experimentally. The work insured that soil replacement depth / footing width ratio of 1.5 was the highest shear strength of tested soil among all the studied cases. It is worth mentioning that, the researchers studied the thickness and type of replacement layer from geotechnical point of view regardless the optimization of total cost of foundation works. 


\section{Optimization Model}

The methodology of this study was taking into account all factors that control the foundation design when using replacement layers beneath shallow foundations resting on medium clay. These factors include increasing bearing capacity, limiting the consolidation settlement within the allowable value, and minimizing the total direct cost of foundation works. Therefore, the problem, which this study deals with, is considered an optimization problem. The mathematical model was formulated comprising choosing two decision variables, thickness and type of replacement layer, to achieve the objective within set of constraints. A better solution is obtained if the direct cost of foundation works can be minimized. The solution is optimum when the cost is the lowest between all feasible solutions and satisfies the bearing capacity and consolidation settlement conditions at the same time. The solution alternatives are limited to some constraints. This optimization problem can be classified to Mixed Integer Nonlinear Programming (MINLP) which refers to mathematical programming with continuous and binary decision variables and nonlinearities in the objective function and the constraints [10].

\section{Objective Function}

The main objective function for this optimization model is to minimize the total direct cost of foundation works that includes direct cost of excavation, plain concrete, reinforced concrete for footings and ground beams, dewatering, replacement material with compaction and backfilling. Equation (1) represents the objective function used for the optimization model. In this equation, reinforced concrete for ground beams was assumed to be $30 \%$ of the volume of reinforced concrete for footings.

Total direct cost

$$
\begin{aligned}
& =[\mathrm{A} \times(\mathrm{Df}+\mathrm{Hr}) \times \mathrm{Cexc}]+[\mathrm{A} \times(\mathrm{tpc}) \times \mathrm{Cpc}] \\
& +[(\mathrm{Nf} \times \mathrm{L} \times \mathrm{B} \times \mathrm{t} \times \mathrm{CRC})+0.3(\mathrm{Nf} \times \mathrm{L} \times \mathrm{B} \times \mathrm{t} \times \mathrm{CRC})] \\
& +[\mathrm{A} \times \text { dew } \times \mathrm{Cdew}]+[\mathrm{A} \times \mathrm{Hr} \times \mathrm{Crep}] \\
& +[\text { volume of back fill } \times \mathrm{Cbf}]
\end{aligned}
$$

\section{Decision Variables}

The decision variables for this optimization model are:

- Replacement layer thickness $\left(\mathrm{H}_{\mathrm{r}}\right)$ which is a decision variable varies from 0 to $3 \mathrm{~m}$ meter throughout this study.

- Type of replacement layer among four mixes, presented in Table (1). Those are the most commonly used replacement fill in case studies and practice. Type of replacement is defined in the optimization model as a binary decision variable.

Table 1: The Four Types of Replacement Layer Used in the Research and its Main Properties After (Abdel Salam, 2007)

\begin{tabular}{lcccc}
\hline Replacement Soil Type & $\begin{array}{c}\gamma_{\mathbf{r d r y}} \\
\left(\mathbf{K N} / \mathbf{m}^{\mathbf{3}}\right)\end{array}$ & $\begin{array}{c}\gamma_{\mathbf{r} \text { sat }} \\
\left(\mathbf{K N} / \mathbf{m}^{\mathbf{3}}\right)\end{array}$ & $\mathbf{C}$ & $\boldsymbol{\emptyset}_{\mathbf{r}}$ \\
\hline Sand & 17.8 & 20.9 & 0 & $35^{\circ}$ \\
Sand \& Gravel 0 [1:1] & 18.9 & 21.6 & 0 & $43^{\circ}$ \\
Sand \& Gravel 0 [1:2] & 19.3 & 21.8 & 0 & $44^{\circ}$ \\
Sand \& Gravel 0 \& Gravel1 [1:1:1] & 20 & 22.3 & 0 & $45^{\circ}$ \\
\hline
\end{tabular}




\section{Constraints}

Set of constraints are used to allow the decision variables to take on certain values but exclude others. The solution is only considered to be feasible when the following constrains are satisfied.

Consolidation settlement constraint

$$
\mathrm{Sc}=\sum \frac{\mathrm{Cc} \times \mathrm{Hi}}{(1+\mathrm{e} 0)} \log \left[\frac{\mathrm{P} 0 \mathrm{i}+\Delta \mathrm{Pi}}{\mathrm{P} 0 \mathrm{i}}\right] \leq 0.05 \mathrm{~m}
$$

where: The Egyptian code of practice for soil mechanics and design of foundation [11] states that the max acceptable total settlement of shallow footings resting on clayey soil $=100-150$ $\mathrm{mm}$, this value includes the consolidation settlement, the secondary settlement and the immediate settlement. Here in, the acceptable consolidation settlement is considered (50 $\mathrm{mm})$.

- The model only selects one mix of materials between the predefined four replacement mixes.

- $\mathrm{H}_{\mathrm{r}} \geq 0, \mathrm{H}_{\mathrm{r}} \leq 3 \mathrm{~m}$

According to the practical constructability purposes

- Design constraints

$$
\begin{gathered}
\mathrm{q}_{\mathrm{sh}}=\frac{\mathrm{Qsh}}{\mathrm{B} \times \mathrm{d}} \leq 0.45 \mathrm{~N} / \mathrm{mm}^{2} \text { and } \mathrm{q}_{\mathrm{pun}}=\frac{\mathrm{Qp}}{\mathrm{Ap}} \leq 0.90 \mathrm{~N} / \mathrm{mm}^{2} \\
\mathrm{t}_{\min } \geq 300 \mathrm{~mm} \text { and } \mathrm{t}_{\min } \geq \mathrm{b}
\end{gathered}
$$

According to the Egyptian code of practice for R.c. Structures [12]

\section{Computer Model}

The computer model is designed based on the mathematical model. The flow chart, illustrated in Figure (2), explains how the model works. The user has to enter details of the soil profile, number of columns, the column load and area of the site. Then, the model uses initial value for replacement layer thickness between 0 to $3 \mathrm{~m}$ and one of the predefined replacement mixes. Model starts to make bearing capacity calculation to get allowable bearing capacity value and use it in calculating the expected consolidation settlement that must not exceed $50 \mathrm{~mm}$ according to the assumed limitations. Subsequently, footing design is performed and total direct cost is calculated. The model repeats the previous steps until it reaches the optimum replacement thickness and the replacement mix that satisfies the minimum total direct cost.

A key to solving the research problem is to select the appropriate solving method. Three solving methods were adopted to find the optimal solutions: The GRG Nonlinear solving method which uses the Generalized Reduced Gradient (GRG2) code, the simplex LP solving method which uses the branch and bound method and the Evolutionary solving method which uses a variety of genetic algorithm and local search methods [13]. The two deterministic solving methods, GRG nonlinear and simplex LP, had been tried to find the optimal solution. The model stopped working and could not find any values for the decision variables that allow all of the constraints to be satisfied simultaneously. Since the resulting 
optimization problem involved complexities like discrete, continuous variables, nonlinearity in objective function and constraints also the deterministic methods were not effective to solve this problem, The Evolutionary solving method was successfully used to solve the research problem.

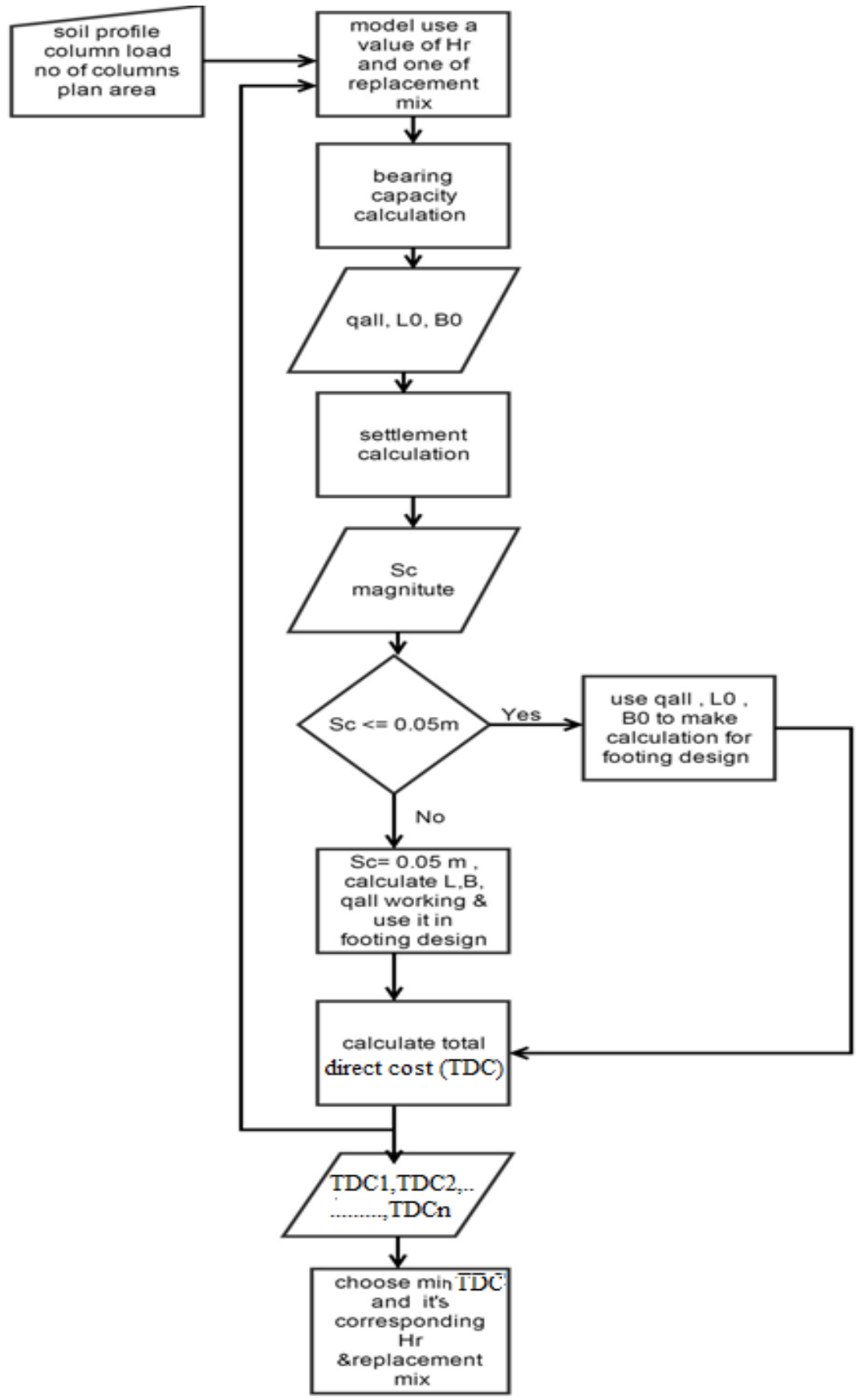

Figure 2: Model solution flow chart

Verification and validation are executed to ensure that model is correct and reliable for specific limitations. Model verification is performed on three different cases by comparing the model solutions, to the manual solutions. Based on the achieved results shown in Table (2), the model gave the same results as the manual method. Thus the model in this research is acceptable and correct for the predefined limitations and assumptions. Validation is performed to demonstrate that the model is operational. The model validation is carried 
out by comparing the model solutions for four real case studies with the solutions recommended by consultants based on experience. Based on validation results shown in Table (3), using the model resulted in a cost saving between 22 to $37 \%$ compared to consultant's recommendations based on experience.

Table 2: Manual and Computer Solutions of the Model Verification Cases

\begin{tabular}{|c|c|c|c|c|}
\hline Case & $\begin{array}{c}\text { Soil } \\
\text { Properties }\end{array}$ & & $\begin{array}{l}\text { Manual } \\
\text { Solution }\end{array}$ & $\begin{array}{c}\text { Computer } \\
\text { Solution }\end{array}$ \\
\hline \multirow{3}{*}{$\begin{array}{c}\text { Verification } \\
\text { Case (1) }\end{array}$} & $\begin{array}{ll}\text { - } & \gamma_{\mathrm{c}}=17.3 \mathrm{KN} / \mathrm{m}^{3} \\
\text { - } & \mathrm{C}=30 \mathrm{KN} / \mathrm{m}^{2} \\
\text { - } & \mathrm{C}_{\mathrm{c}}=0.22 \\
\text { - } & \mathrm{e}_{\mathrm{o}}=0.633\end{array}$ & $\begin{array}{l}\text { Replacement } \\
\text { Type }\end{array}$ & Sand & Sand \\
\hline & $\begin{array}{ll}- & \mathrm{H}_{\mathrm{c}}=6.0 \mathrm{~m} \\
- & \mathrm{D}_{\mathrm{f}}=2.0 \mathrm{~m} \\
- & \mathrm{G} . \mathrm{W} . \mathrm{T} \text { depth }=2.0 \\
\text { - } & \text { Building area }=2450\end{array}$ & $\begin{array}{l}\text { Replacement } \\
\text { Thickness }\left(\mathrm{H}_{\mathrm{r}}\right)\end{array}$ & $1.50 \mathrm{~m}$ & $1.50 \mathrm{~m}$ \\
\hline & $\begin{array}{ll}\text { - } & \text { Column load }=755 \\
\mathrm{KN} \\
\text { - } & \text { Number of columns } \\
& =70\end{array}$ & $\begin{array}{l}\text { Total Direct Cost } \\
\text { of Foundation } \\
\text { Works (EGP) }\end{array}$ & $1,025,490$ & $1,025,490$ \\
\hline \multirow{3}{*}{$\begin{array}{c}\text { Verification } \\
\text { Case (2) }\end{array}$} & $\begin{array}{ll}\text { - } & \gamma_{\mathrm{c}}=17.6 \mathrm{KN} / \mathrm{m}^{3} \\
\text { - } & \mathrm{C}=25 \mathrm{KN} / \mathrm{m}^{2} \\
\text { - } & \mathrm{C}_{\mathrm{c}}=0.294 \\
\text { - } & \mathrm{e}_{\mathrm{o}}=1.181\end{array}$ & $\begin{array}{l}\text { Replacement } \\
\text { Type }\end{array}$ & Sand & Sand \\
\hline & $\begin{array}{ll}\text { - } & \mathrm{H}_{\mathrm{c}}=5.0 \mathrm{~m} \\
\text { - } & \mathrm{D}_{\mathrm{f}}=2.0 \mathrm{~m} \\
\text { - } & \mathrm{G} . \mathrm{W} . \mathrm{T} \text { depth }=1.0 \\
\text { - } & \text { Building area }=2450 \\
\mathrm{~m}^{2}\end{array}$ & $\begin{array}{l}\text { Replacement } \\
\text { Thickness }\left(\mathrm{H}_{\mathrm{r}}\right)\end{array}$ & $1.50 \mathrm{~m}$ & $1.50 \mathrm{~m}$ \\
\hline & $\begin{array}{ll}\text { - } & \text { Column load }=755 \\
\text { KN } \\
\text { - }\end{array}$ & $\begin{array}{l}\text { Total Direct Cost } \\
\text { of Foundation } \\
\text { Works (EGP) }\end{array}$ & $1,168,111$ & $1,168,111$ \\
\hline \multirow{3}{*}{$\begin{array}{c}\text { Verification } \\
\text { Case (3) }\end{array}$} & $\begin{array}{ll}\text { - } & \gamma_{c}=19.5 \mathrm{KN} / \mathrm{m}^{3} \\
\text { - } & \mathrm{C}=130 \mathrm{KN} / \mathrm{m}^{2} \\
\text { - } & \mathrm{C}_{\mathrm{c}}=0.184 \\
\text { - } & \mathrm{e}_{0}=0.788\end{array}$ & $\begin{array}{l}\text { Replacement } \\
\text { Type }\end{array}$ & $\begin{array}{c}\text { Sand: } \\
\text { Crushed } \\
\text { stone } 0 \\
{[1: 1]}\end{array}$ & $\begin{array}{c}\text { Sand: } \\
\text { Crushed } \\
\text { stone } 0 \\
{[1: 1]}\end{array}$ \\
\hline & $\begin{array}{ll}\text { - } & \mathrm{H}_{\mathrm{c}}=6.0 \mathrm{~m} \\
\text { - } & \mathrm{D}_{\mathrm{f}}=2.0 \mathrm{~m} \\
\text { - } & \mathrm{G} . \mathrm{W} . \mathrm{T} \text { depth }=2.0 \\
\text { - } & \text { Building area }=2450\end{array}$ & $\begin{array}{l}\text { Replacement } \\
\text { Thickness }\left(\mathrm{H}_{\mathrm{r}}\right)\end{array}$ & $0.70 \mathrm{~m}$ & $0.70 \mathrm{~m}$ \\
\hline & $\begin{array}{ll}\mathrm{m}^{2} \\
\text { - } & \text { Column load }=755 \\
\mathrm{KN} \\
\text { - } & \text { Number of columns } \\
=70\end{array}$ & $\begin{array}{l}\text { Total Direct Cost } \\
\text { of Foundation } \\
\text { Works (EGP) }\end{array}$ & 798,637 & 798,637 \\
\hline
\end{tabular}


Table 3: Comparison between Consultant Recommendation and Model Solution for the Validation Cases

\begin{tabular}{|c|c|c|c|c|c|}
\hline Case & $\begin{array}{c}\text { Soil } \\
\text { Properties }\end{array}$ & & $\begin{array}{c}\text { Consultant } \\
\text { Recommenda } \\
\text {-tion }\end{array}$ & Model solution & $\begin{array}{c}\text { Cost } \\
\text { saving }\end{array}$ \\
\hline $\begin{array}{l}\text { Validation } \\
\text { Case study } \\
\text { (1) }\end{array}$ & $\begin{array}{l}-\mathrm{D}_{\mathrm{f}}=1.50 \mathrm{~m} \\
\text { - } \gamma_{\mathrm{o}}=16 \mathrm{KN} / \mathrm{m}^{3} \\
\text { - } \mathrm{H}_{\mathrm{c}}=3.2 \mathrm{~m} \\
\text { - } \gamma_{\mathrm{c}}=17.8 \\
\mathrm{KN} / \mathrm{m}^{3} \\
\text { - } \mathrm{C}=76 \mathrm{KN} / \mathrm{m}^{2} \\
\text { - } \mathrm{C}_{\mathrm{c}}=0.192 \\
\text { - } \mathrm{e}_{\mathrm{o}}=0.964 \\
\text { - G.W.T depth }= \\
\text { 1.50 m }\end{array}$ & $\begin{array}{l}\text { Replacement } \\
\text { Type } \\
\text { Replacement } \\
\text { Thickness } \\
\left(\mathrm{H}_{\mathrm{r}}\right) \\
\text { Total Direct } \\
\text { Cost of } \\
\text { Foundation } \\
\text { Works } \\
\text { (EGP) }\end{array}$ & $\begin{array}{c}\text { Sand: crushed } \\
\text { stone } 0[1: 1]\end{array}$ & $\begin{array}{c}\text { Sand: crushed } \\
\text { stone } 0: \text { crushed } \\
\text { stone } 1 \\
{[1: 1: 1]}\end{array}$ & $34 \%$ \\
\hline $\begin{array}{l}\text { Validation } \\
\text { Case study } \\
\text { (2) }\end{array}$ & $\begin{array}{l}-\mathrm{D}_{\mathrm{f}}=1.50 \mathrm{~m} \\
\text { - } \gamma_{\mathrm{o}}=16 \mathrm{KN} / \mathrm{m}^{3} \\
\text { - } \mathrm{H}_{\mathrm{c}}=6.0 \mathrm{~m} \\
\text { - } \gamma_{\mathrm{c}}=17.6 \\
\mathrm{KN} / \mathrm{m}^{3} \\
\text { - } \mathrm{C}=47 \mathrm{KN} / \mathrm{m}^{2} \\
\text { - } \mathrm{C}_{\mathrm{c}}=0.32 \\
\text { - } \mathrm{e}_{\mathrm{o}}=0.873 \\
\text { - G.W.T depth }= \\
\text { 0.00 m }\end{array}$ & $\begin{array}{l}\text { Replacement } \\
\text { Type } \\
\text { Replacement } \\
\text { Thickness } \\
\left(\mathrm{H}_{\mathrm{r}}\right) \\
\text { Total Direct } \\
\text { Cost of } \\
\text { Foundation } \\
\text { Works } \\
\text { (EGP) }\end{array}$ & $\begin{array}{c}\text { Sand: crushed } \\
\text { stone } 0[1: 1]\end{array}$ & $\begin{array}{c}\text { Sand: crushed } \\
\text { stone } 0: \text { crushed } \\
\text { stone } 1[1: 1: 1]\end{array}$ & $28.5 \%$ \\
\hline $\begin{array}{l}\text { Validation } \\
\text { Case study } \\
\text { (3) }\end{array}$ & $\begin{array}{l}\text { - } \mathrm{D}_{\mathrm{f}}=1.50 \mathrm{~m} \\
\text { - } \gamma_{\mathrm{o}}=16 \mathrm{KN} / \mathrm{m}^{3} \\
\text { - } \mathrm{H}_{\mathrm{c}}=5.5 \mathrm{~m} \\
\text { - } \gamma_{\mathrm{c}}=16.9 \\
\mathrm{KN} / \mathrm{m}^{3} \\
\text { - } \mathrm{C}=35 \mathrm{KN} / \mathrm{m}^{2} \\
\text { - } \mathrm{C}_{\mathrm{c}}=0.342 \\
\text { - } \mathrm{e}_{\mathrm{o}}=0.972 \\
\text { - G.W.T depth }= \\
\text { 0.00 m }\end{array}$ & $\begin{array}{l}\text { Replacement } \\
\text { Type } \\
\text { Replacement } \\
\text { Thickness } \\
\left(\mathrm{H}_{\mathrm{r}}\right) \\
\text { Total Direct } \\
\text { Cost of } \\
\text { Foundation } \\
\text { Works } \\
\text { (EGP) }\end{array}$ & $\begin{array}{c}\text { Sand: crushed } \\
\text { stone } 0[1: 1] \\
1.00 \mathrm{~m}\end{array}$ & $\begin{array}{c}\text { Sand: crushed } \\
\text { stone } 0[1: 1] \\
1.80 \mathrm{~m}\end{array}$ & $37 \%$ \\
\hline $\begin{array}{l}\text { Validation } \\
\text { Case study } \\
\text { (4) }\end{array}$ & $\begin{array}{l}\text { - } \mathrm{D}_{\mathrm{f}}=2.00 \mathrm{~m} \\
-\gamma_{\mathrm{o}}=16 \mathrm{KN} / \mathrm{m}^{3} \\
\text { - } \mathrm{H}_{\mathrm{c}}=6.0 \mathrm{~m} \\
\text { - } \gamma_{\mathrm{c}}=17.6 \\
\mathrm{KN} / \mathrm{m}^{3} \\
\text { - } \mathrm{C}=30 \mathrm{KN} / \mathrm{m}^{2} \\
\text { - } \mathrm{C}_{\mathrm{c}}=0.45 \\
\text { - } \mathrm{e}_{\mathrm{o}}=1.65 \\
\text { - G.W.T depth }= \\
\text { 2.00 m }\end{array}$ & $\begin{array}{l}\text { Replacement } \\
\text { Type } \\
\text { Replacement } \\
\text { Thickness } \\
\left(\mathrm{H}_{\mathrm{r}}\right) \\
\text { Total Direct } \\
\text { Cost of } \\
\text { Foundation } \\
\text { Works } \\
\text { (EGP) }\end{array}$ & $\begin{array}{l}\text { Sand: crushed } \\
\text { stone } 0[1: 2]\end{array}$ & $1,340,800$ & $22 \%$ \\
\hline
\end{tabular}




\section{Parametric Study}

A parametric study is carried out to investigate the effect of three parameters on the replacement layer thickness and type by using the proposed computer model. The studied parameters were the thickness and properties of the original medium clay layer and the location of the ground water table from the ground level.

\section{Studied Parameters}

\section{Medium Clay Layer Properties}

The natural soil profile of the problem contained medium clay layer, six values of clayey soil undrained cohesion are considered in the study, as they present the medium state of clay. Table (3) presents the six clay consistencies and their corresponding main parameters.

Table 4: The Six Types of Medium Clay and Their Parameters (E. C. P., 2012)

\begin{tabular}{cccc} 
& $\begin{array}{c}\mathbf{C} \\
\left(\mathbf{K N} / \mathbf{m}^{2}\right)\end{array}$ & $\frac{\boldsymbol{C c}}{\mathbf{1 + e \boldsymbol { O }}}$ & $\begin{array}{c}\mathbf{Y}_{\mathbf{c s a t}} \\
\left(\mathbf{K N} / \mathbf{m}^{\mathbf{3}}\right)\end{array}$ \\
\hline $\mathbf{A}$ & 25 & 0.207 & 17.3 \\
$\mathbf{B}$ & 30 & 0.189 & 17.6 \\
$\mathbf{C}$ & 35 & 0.171 & 17.9 \\
$\mathbf{D}$ & 40 & 0.152 & 18.1 \\
$\mathbf{E}$ & 45 & 0.134 & 18.4 \\
$\mathbf{F}$ & 50 & 0.116 & 18.7 \\
\hline
\end{tabular}

Medium Clay Layer Thickness $\left(H_{c}\right)$

Although the model is valid to be used in case of clay layer thickness equal or less than 20 $\mathrm{m}$, the analysis is performed on clay layer thickness $(2,3,4,5,6 \mathrm{~m})$.

Ground Water Table Location (G.W.T)

Ground water table is assumed to be constant for the same case; also it is always on or above the upper surface of clay. Five values of G.W.T depth are assumed in the study $(0.1,0.5,1.0$, $1.5,2.0 \mathrm{~m}$ ) beneath the ground surface.

The studied parameters are used to form 150 case studies. Other input data such as the foundation depth, unit weight of fill, the total building area, column load and number of columns are considered constant for all case studies and have the following values $2 \mathrm{~m}, 16$ $\mathrm{KN} / \mathrm{m}^{3}, 2450 \mathrm{~m}^{2}, 755 \mathrm{KN}$ and 70 columns respectively.

\section{Results Analysis}

Based on all the variations made to the studied parameters, the optimum replacement layer thickness and type corresponding to minimum total direct cost of foundation works are determined at all the 150 case studies. Throughout reviewing all the results, the next observations are investigated. 
Relationship between the Replacement Layer Thickness $\left(H_{r}\right)$ and the Total Direct Cost of Foundation Works

Figures (3) and (4) represent the relationship between the replacement layer thickness $\left(\mathrm{H}_{\mathrm{r}}\right)$ and the total direct cost of foundation works for some of the studied cases and the same trend is achieved for all the studied cases.

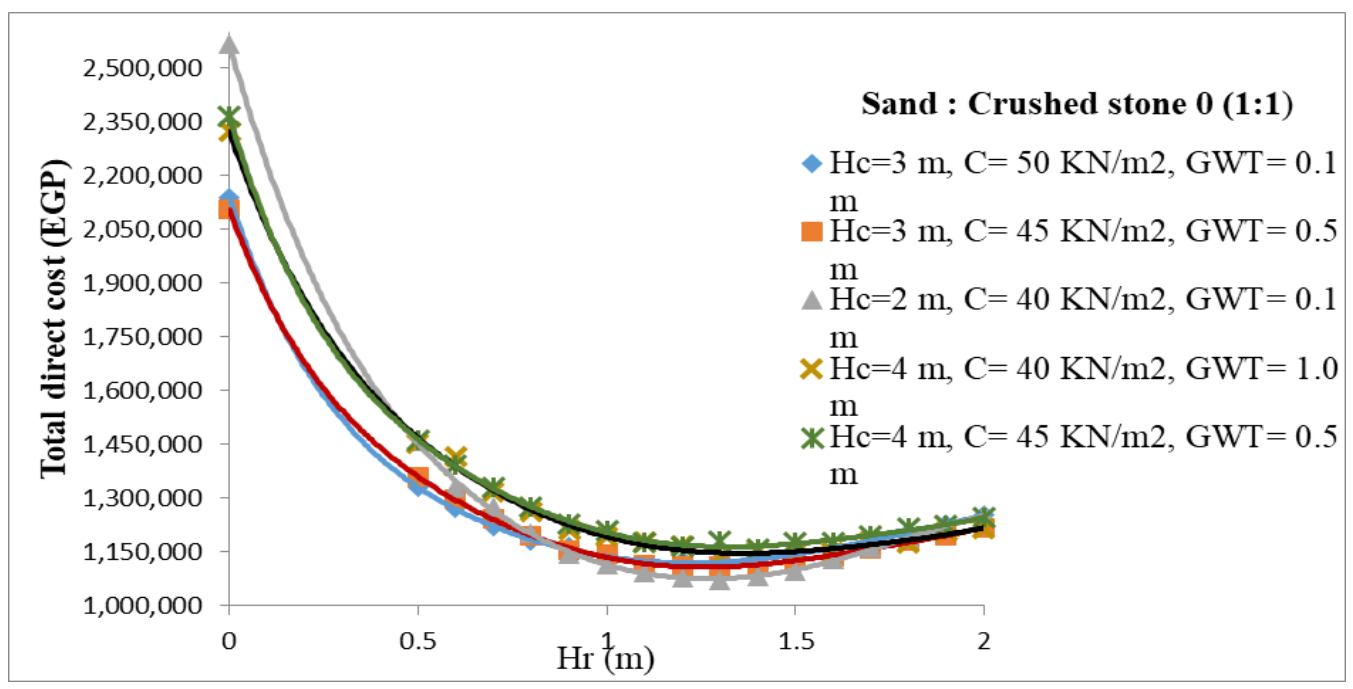

Figure 3: Relationship between the replacement layer thickness $\left(\mathrm{H}_{\mathrm{r}}\right)$ and the total direct cost of foundation works for replacement type sand: crushed stone $0(1: 1)$

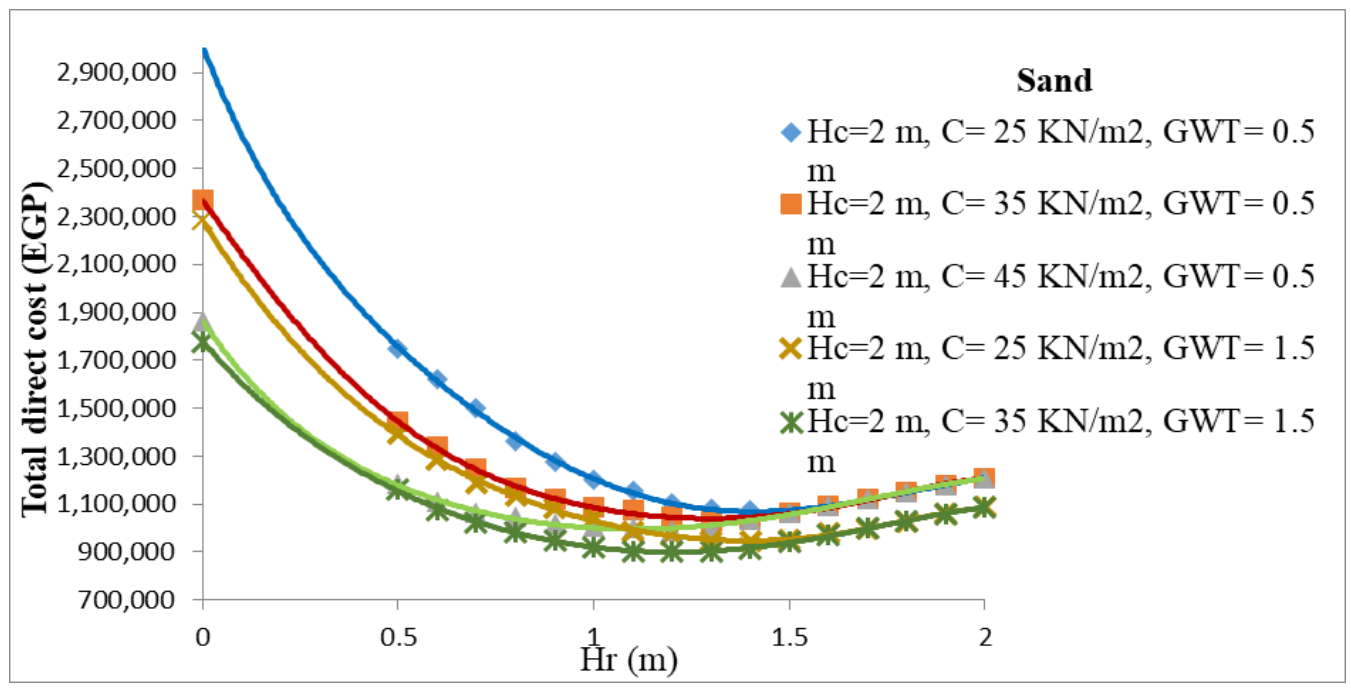

Figure 4: Relationship between the replacement layer thickness $\left(\mathrm{H}_{\mathrm{r}}\right)$ and the total direct cost of foundation works for replacement type sand

The obtained results of all studied cases showed that when the replacement layer thickness increases, the total direct cost decreases but after a certain replacement layer thickness, the total direct cost starts to increase gradually as illustrated in figure (2) and (3). This increase in the total direct cost of foundation works can be explained by that, the increase of the replacement layer thickness produces a higher bearing capacity and thus higher settlement. The specification/code limits for settlement present a constraint on the allowable working bearing capacity. Therefore, the foundation size increases, resulting in higher construction costs. Hence, an optimal thickness in terms of direct costs is achieved 
due to the code limitations for settlement. Accordingly, the notion of increasing replacement thickness to decrease cost limitlessly showed not viable in this research, and an optimal thickness is usually achieved. For all studied cases, the optimum replacement thickness was always found between 0.7 to 2 meter and the optimum replacement materials were either sand or Sand: crushed stone size 0 with a ratio of (1:1) by volume.

Relationship between Medium Clay Undrained Cohesion (c) and the Optimum Replacement Layer Thickness $\left(H_{r, o p t}\right)$

Figures from (5) and (6) represent the relationship between the clay cohesion (c) and the optimum replacement layer thickness $\left(\mathrm{H}_{\mathrm{r}, \mathrm{opt}}\right)$ for various clay layer thicknesses starting from 2 to $6 \mathrm{~m}$ and by changing the ground water table location.

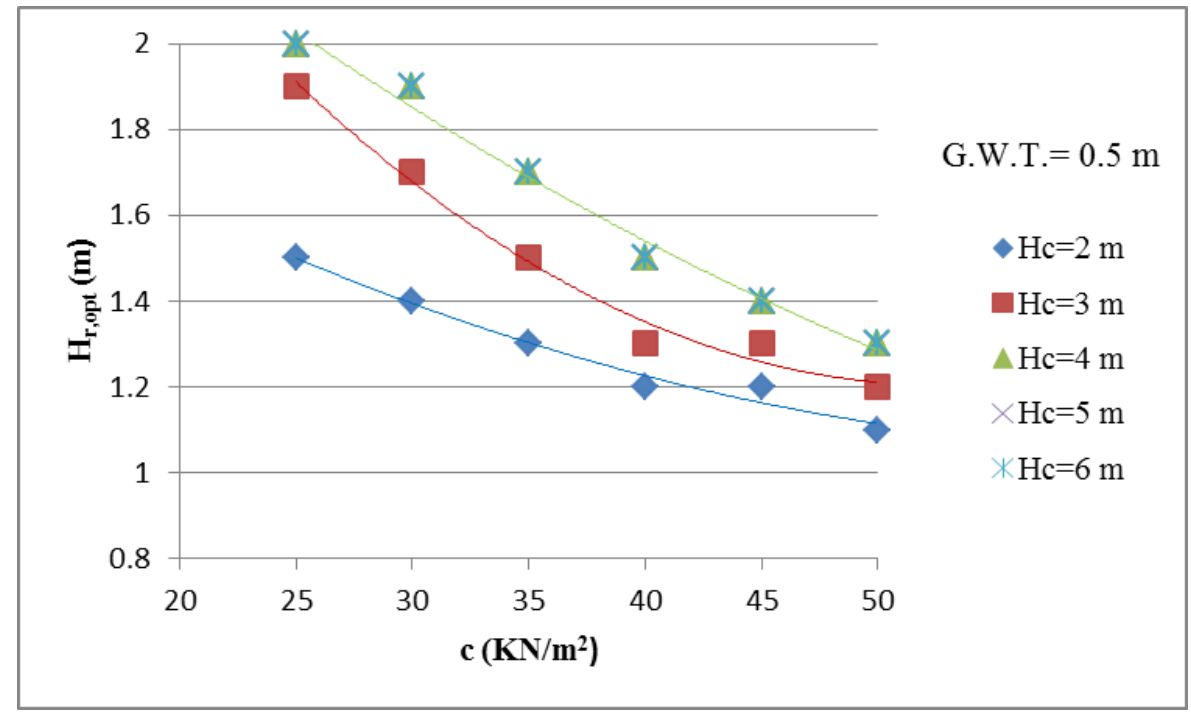

Figure 5: Relationship between medium clay soil cohesion (c) and the optimum replacement layer thickness $\left(\mathrm{H}_{\mathrm{r}, \mathrm{opt}}\right)$ for various clay layer thicknesses and G.W.T depth $=$ $0.5 \mathrm{~m}$

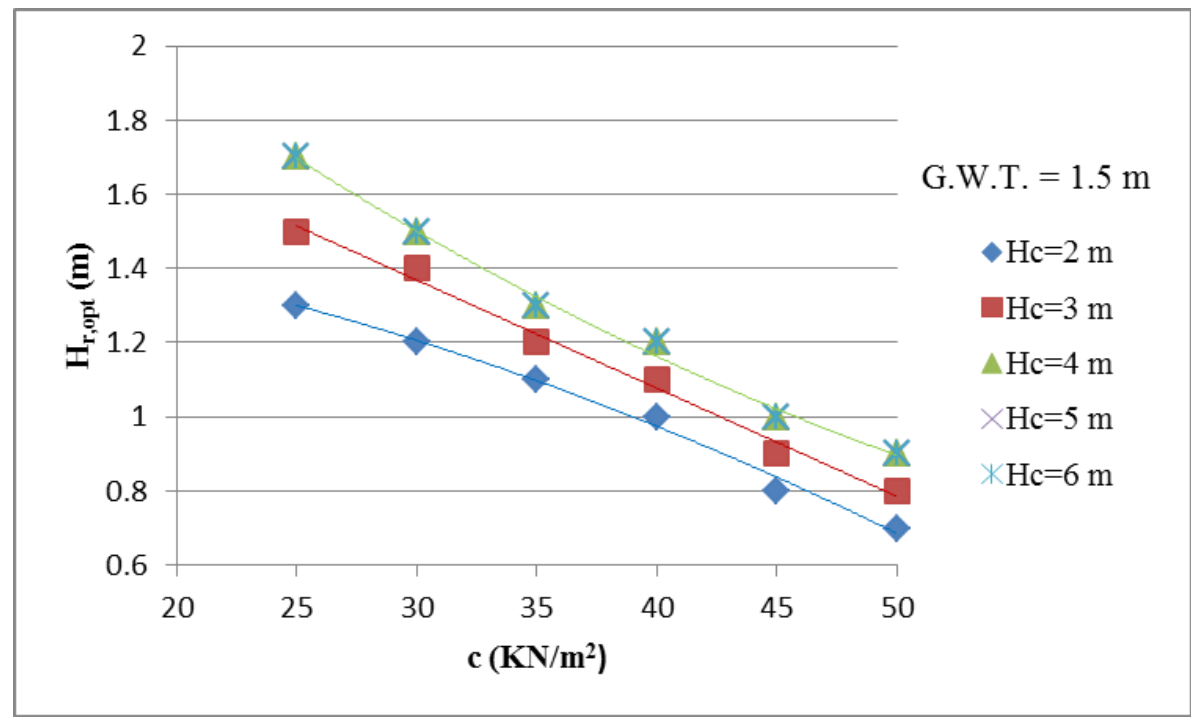

Figure 6: Relationship between medium clay soil cohesion (c) and the optimum replacement layer thickness $\left(\mathrm{H}_{\mathrm{r}, \mathrm{ppt}}\right)$ for various clay layer thicknesses and $\mathrm{G} . W . T$ depth= 
For all studied cases, as the previous figures show, there is a reverse relationship between the undrained cohesion of the original medium clay soil and the optimum replacement layer thickness.

Relationship between the Ratio of Clay Layer Thickness to the Footing Width $\left(H_{c} / B\right)$ and the Optimum Replacement Layer Thickness $\left(H_{\text {ropt }}\right)$

Figures from (7) and (8) represent the relationship between the ratio of clay layer thickness to the corresponding footing width $\left(\mathrm{H}_{\mathrm{c}} / \mathrm{B}\right)$ and the optimum replacement layer thickness for different medium clay values of cohesion $\left(\mathrm{c}=25,30,35,40,45,50 \mathrm{KN} / \mathrm{m}^{2}\right)$ and by changing the location of water table.

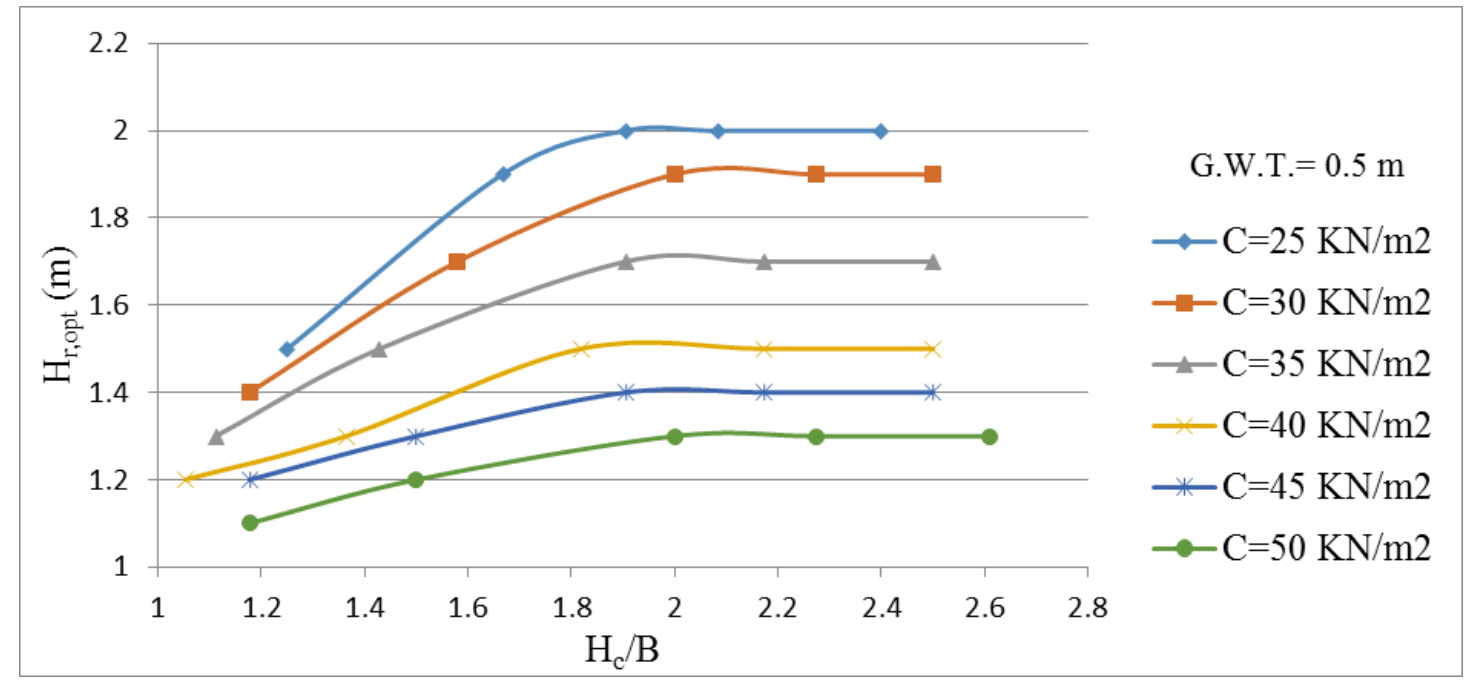

Figure 7: Relationship between the ratio of clay layer thickness to the footing width $\left(\mathrm{H}_{\mathrm{c}} / \mathrm{B}\right)$ and the optimum replacement layer depth $\left(\mathrm{H}_{\mathrm{r}, \mathrm{opt}}\right)$ for various clay layer cohesions and G.W.T depth $=0.5 \mathrm{~m}$

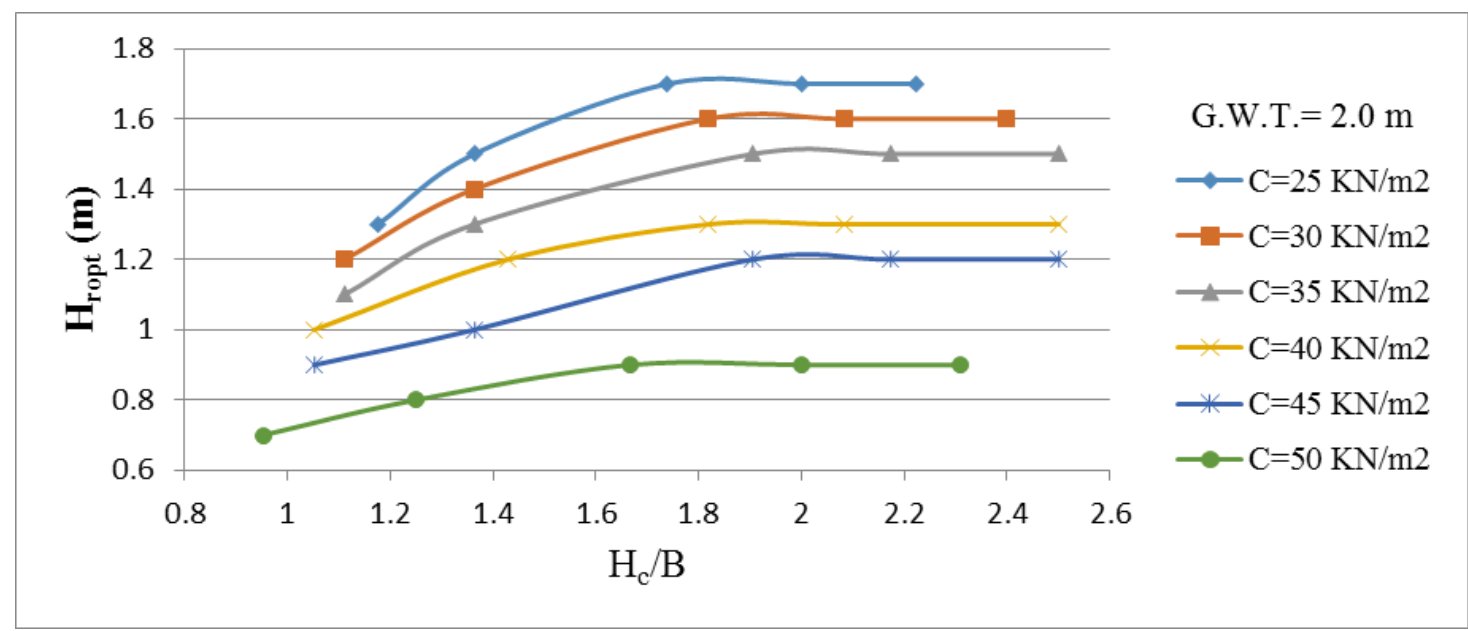

Figure 8: Relationship between the ratio of clay layer thickness to the footing width $\left(\mathrm{H}_{\mathrm{c}} / \mathrm{B}\right)$ and the optimum replacement layer depth $\left(\mathrm{H}_{\mathrm{r}, \text { opt }}\right)$ for various clay layer cohesions and G.W.T depth $=2.0 \mathrm{~m}$

Generally, from the previous figures, optimum replacement layer thickness $\left(\mathrm{H}_{\mathrm{r}, \mathrm{opt}}\right)$ increases gradually with increasing the ratio $\left(\mathrm{H}_{\mathrm{c}} / \mathrm{B}\right)$ until certain point , then the optimum replacement thickness turns out to be constant. The reason may be that the upper part of clay 
layer is largely influenced by stress increase caused by foundation therefore, the majority of consolidation settlement is related to the upper part of clay layer. So, higher ratio of $\left(\mathrm{H}_{\mathrm{c}} / \mathrm{B}\right)$ had a slight effect on the value of consolidation settlement and subsequently on the thickness of replacement layer $\left(\mathrm{H}_{\mathrm{r}}\right)$ which is required to improve the clay performance.

\section{Relationship between G.W.T. Depth and the Optimum Replacement Layer Thickness (Hr,opt)}

Figure (9) shows the relationship between the depth of ground water table from the ground level and the optimum replacement layer thickness for different clay layer thickness and properties. It is noticed that, the optimum thickness of replacement layer $\left(\mathrm{H}_{\mathrm{r}, \mathrm{opt}}\right)$ is inversely proportional to the depth of G.W.T.

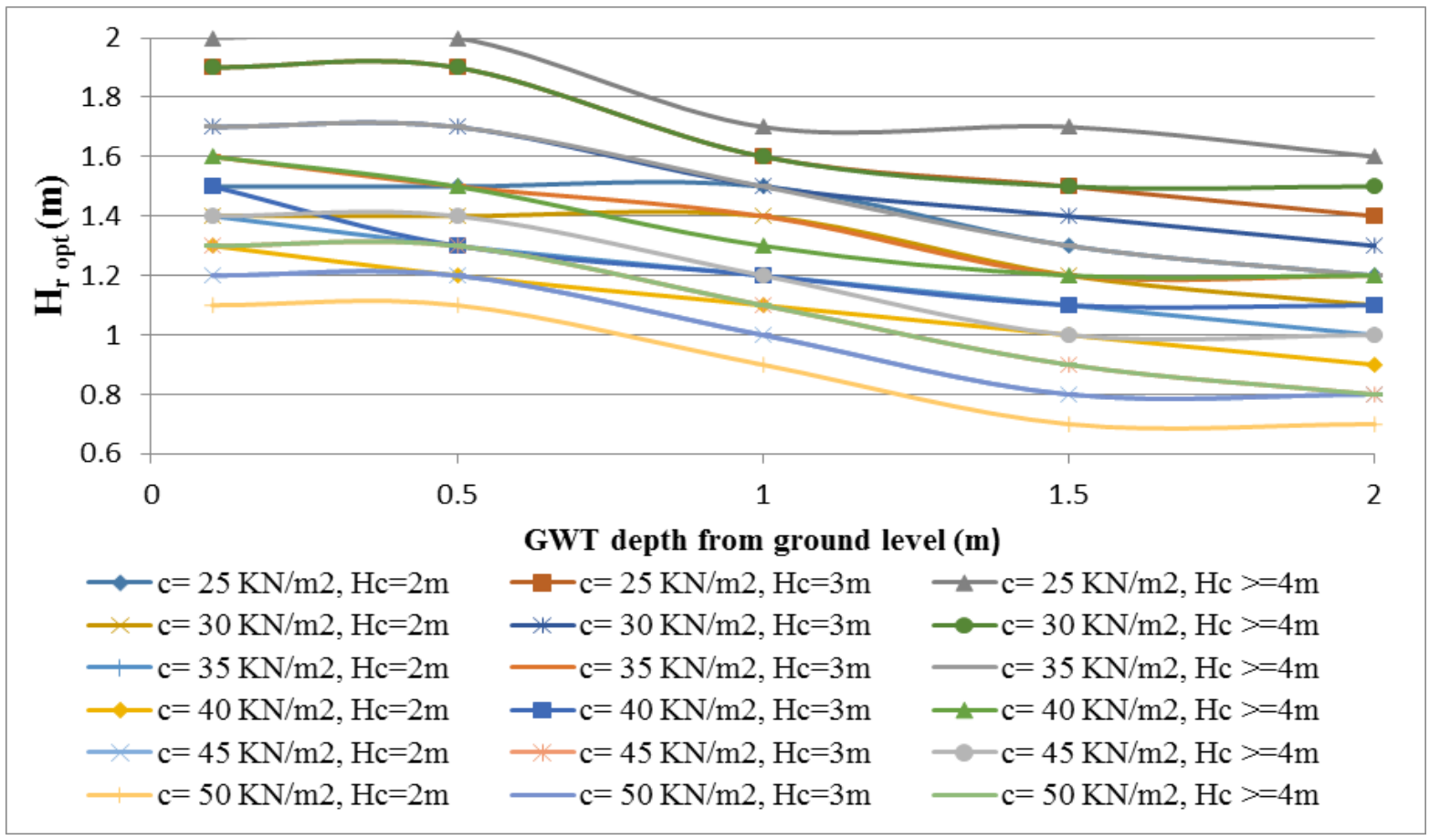

Figure 9: Relationship between G.W.T depth and the optimum replacement layer thickness $\left(\mathrm{H}_{\mathrm{r}, \mathrm{opt}}\right)$ for various clay layer cohesions and thicknesses

\section{Conclusions}

The optimum thickness and type of replacement layer beneath shallow footings resting on medium clay in terms of total direct costs of foundation works was researched in this paper. After investigating the research problem, the main conclusions were

- A computer model was developed which may help geotechnical engineers in predicting the optimum type and thickness of replacement layer to achieve the minimum total direct cost of foundation works as well as increasing the bearing capacity and controlling consolidation settlement. Based on validation results, using the proposed model resulted in a total direct cost saving ranged from 22 to $37 \%$ compared to consultant's recommendations based on experience.

- The study revealed that the replacement layer thickness $\left(\mathrm{H}_{\mathrm{r}}\right)$ had a clear optimum point $\left(\mathrm{H}_{\mathrm{r}, \mathrm{opt}}\right)$, contrary to the previous notion of a linear increasing relationship between direct cost and $\mathrm{H}_{\mathrm{r}}$. 
- Based on all studied cases, the optimum replacement thickness was always less than $2 \mathrm{~m}$ and varied from 0.7 to $2 \mathrm{~m}$ and the optimum replacement materials were sand and sand: crushed stone size 0 with a ratio of $(1: 1)$ by volume.

- A parametric study was carried out to study the effect of thickness of clay layer $\left(\mathrm{H}_{\mathrm{c}}\right)$, the clay compression index and initial voids ratio in terms of $\left(\frac{\mathrm{Cc}}{1+\mathrm{e} 0}\right)$, the saturated unit weight of clay layer $\left(\gamma_{\mathrm{sat}}\right)$, the clayey soil cohesion $(\mathrm{C})$ and the depth of ground water table (G.W.T) on determining the optimum type and thickness of replacement soil. Based on the results and the analysis of the parametric study, it was noticed that:

- When clay cohesion (c) increased, the optimum replacement layer thickness $\left(\mathrm{H}_{\mathrm{r}, \mathrm{opt}}\right)$ decreased for various clay layer thicknesses and ground water table locations.

- The optimum replacement thickness $\left(\mathrm{H}_{\mathrm{r}, \mathrm{opt}}\right)$ increased gradually by increasing the ratio of clay layer thickness to the footing width $\left(\mathrm{H}_{\mathrm{c}} / \mathrm{B}\right)$ up to a certain point, then the relationship was constant.

- The optimum replacement thickness $\left(\mathrm{H}_{\mathrm{r}, \mathrm{opt}}\right)$ decreased, when the ground water depth (G.W.T) increased.

\section{References}

[1] B.M. Das, Principles of Foundation Engineering, $7^{\text {th }}$ Edition, Cengage Learning, Stamford, Connecticut, United States of America, 2011.

[2] M.Y. Fattah, M.A. Alneami, and A.S. Alsuhaily, "Improvement of bearing capacity of footings on soft clay by partial soil replacement technique," Paper presented at The Second International Conference of Buildings, Construction and Environmental Engineering, American University of Beirut, Beirut, Lebanon, 2015.

[3] A.K. Gaber, "The uncertainties of using replacement soil in controlling settlement," Journal of American Science, Vol. 8, No. 12, pp. 662-665, 2012. doi: 10.1201/b10554224.

[4] M.M. Abdel Fatah, Improvement of Bearing Capacity of Soft Clay Soil Beneath Shallow Foundation Using Cohesionless Soil Replacement, Thesis (Master's), University of Menoufiya, Menoufiya, Egypt, 2014.

[5] S.E. Abdel Salam, The Effect of Replacement Soil on Reducing Settlement of Footing on Deep Soft Clay Using Numerical Approach, Thesis (Master's), University of Cairo, Cairo, Egypt, 2007.

[6] N.A. Ali, "Controlling collapsibility potential by partial soil replacement," Global Journal of Researches in Engineering: Civil and Structural Engineering, Vol. 16, No. 1, pp. 7-19, 2016. doi: 10.17406

[7] A.A. Zukri, R.B. Nazir, and N.C. Shein, "The settlement evaluation of improved soft clay using leca replacement technique," Paper presented at $20^{\text {th }}$ Southeast Asian Geotechnical Conference, Indonesian Society for Geotechnical Engineering, Jakarta, Indonesia, 2018.

[8] B. Tarawneh, W. Bodour, A. Shatnawi, and K. Alajmib, "Field evaluation and behaviour of the soil improved using dynamic replacement," Journal of Case Studies in Construction Materials, Vol. 10, No. 1, pp. 1-11, 2019. doi: 10.1016/j.cscm.2018.e0021.

[9] K.R. Bell, and J.R. Davie, "Comparison of two ground modification techniques to reduce settlement," Paper presented at Fifth International Conference on Case Histories in Geotechnical Engineering, Missouri University of Science and Technology, New York, United States of America, 2004.

[10] P.C. Varghese, Foundation Engineering, $9^{\text {th }}$ Edition, PHI Learning Private Limited, New Delhi, India, 2012. 
[11] M.R. Bussieck, and A. Pruessner, "Mixed-integer nonlinear programming," SIAG/OPT Newsletter: Views \& News, Vol. 14, No. 1, pp. 19-22, 2003.

[12] Housing and Building Research Centre, Egyptian Code of Practice of Soil Mechanics and Design of Foundations, ECP 202, Ministry of Housing, Utilities and Urban Communities, Giza, Egypt, 2012.

[13] Housing and Building Research Centre, Egyptian Code of Practice of R.C. Structures, ECP 203, Ministry of Housing, Utilities and Urban Communities, Giza, Egypt, 2008.

[14] M. Harmon, Step By Step Optimization With Excel Solver, $2^{\text {nd }}$ Edition, Excel Master Series, United States of America, 2012.

\section{List of Symbols}

- $\mathrm{Y}_{\mathrm{c} \text { sat: }}$ Clay saturated unit weight $\left(\mathrm{KN} / \mathrm{m}^{3}\right)$

- Yo: Fill layer unit weight $\left(\mathrm{KN} / \mathrm{m}^{3}\right)$

- A: Plan area $\left(\mathrm{m}^{2}\right)$

- B: Footing width (m)

- b: Column width

- C: Clay cohesion $\left(\mathrm{KN} / \mathrm{m}^{2}\right)$

- $\mathrm{C}_{\text {exc: }}$ Unit direct cost of excavation

- $\mathrm{C}_{\mathrm{pc}}$ : Unit direct cost of plain concrete

- $\mathrm{C}_{\mathrm{RC}}$ : Unit direct cost of reinforced concrete

- $\mathrm{C}_{\text {dew }}$ : Unit direct cost of dewatering

- Cbf: Unit direct cost of backfill

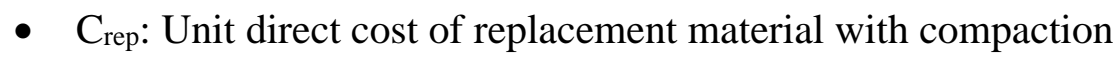

- $\mathrm{C}_{\mathrm{c}}$ : Compression index

- Df: Foundation depth (m)

- $d_{\text {dew: }}$ Dewatering depth (m)

- d: Footing depth

- eo: Initial void ratio

- $\mathrm{H}_{\mathrm{c}}$ : Original clay layer thickness (m)

- $\mathrm{H}_{\mathrm{cm}}$ : Modified clay layer thickness after replacement (m)

- $\mathrm{H}_{\mathrm{r}}$ : Replacement layer thickness (m)

- $\mathrm{H}_{\mathrm{r}, \mathrm{opt}}$ Optimum replacement layer thickness (m)

- $\mathrm{H}_{\mathrm{i}}$ : Thickness of sub layer $\mathrm{i}$ of clay

- L: Footing length (m)

- $\mathrm{L}_{0}, \mathrm{~B}_{0}$ : Initial footing dimension calculated using qall

- $\mathrm{N}_{\mathrm{f}}$ : Number of footings

- Poi: Average effective pressure on clay sub layer i before construction of foundation

- $\Delta \mathrm{P}_{\mathrm{i}}$ : Average increase in effective pressure on clay sub layer i caused by construction of foundation

- $\mathrm{q}_{\mathrm{sh}}$ : Allowable one-way shear stress

- qpun: Allowable punching shear stress

- qall,working: Allowable bearing capacity which satisfies an acceptable consolidation settlement $\leq 0.05 \mathrm{~m}$

- $\mathrm{S}_{\mathrm{c}}$ : Consolidation settlement magnitude (m)

- $\mathrm{T}_{\mathrm{pc}}$ : Plan concrete thickness

- $\mathrm{t}$ : Footing thickness (m)

- $t_{\min }$ : Minimum footing thickness 